\title{
Validity of the Sale and Purchase Deed Made by the Land Deed Official (PPAT) after the Seller Dies
}

\author{
Akhmad Taufan Yogiarto Arba Aris Munandar \\ Notary Master Study Program, Faculty of Law, University of Mataram, Indonesia
}

\begin{abstract}
The purpose of this study was to analyze the validity of the deed of sale and purchase made by the Land Deed Making Officer (PPAT) which was signed after one of the parties died and to understand the responsibilities of the Land Deed Maker Official for the deed he made which was signed after one of the parties died based on the Decision. Mataram District Court Number: 204/Pdt.G/2017/PN.Mtr. The type of research used is juridicalnormative. The approach method used is a statutory approach, a conceptual approach, a case approach, and an analytical approach. Based on the results of the research, it can be concluded that: First, the Sale and Purchase Deed Number: $153 / 2012$ on May 10, 2012, which was used as the basis for the transfer of land rights to SHM Number: 1921/Batu Layar in the Mataram District Court Decision Number: 204/ Pdt.G/2017/PN.Mtr., can be filed for cancellation to the court because it does not meet the legal requirements of an agreement as regulated in Article 1320 of the Civil Code, especially regarding the elements of the agreement of the parties making the agreement. Second, the buyer who is harmed as a result of the Sale and Purchase Deed can file a lawsuit to the District Court so that the PPAT concerned can be held accountable in the form of compensation for compensation costs. The PPAT concerned can also be held accountable administratively, by means of a Buyer who feels aggrieved can file a complaint with the Ministry of Agrarian Affairs and Spatial Planning/Head of the National Land Agency.
\end{abstract}

Keywords: Deed of Sale and Purchase, PPAT, Validity, Liability.

DOI: $10.7176 / \mathrm{JLPG} / 112-13$

Publication date:August $31^{\text {st }} 2021$

\section{INTRODUCTION}

In order to meet the need for land, a person or legal entity can obtain land rights through the process of transfer of land rights. The transfer of land rights can be through 2 (two) means, namely through "legal action (transferred)" and "legal events (switching)".

One way to obtain land rights is by transfer of land rights through buying and selling. In the transfer of land rights through buying and selling there are two parties, namely the seller and the buyer. In the sale and purchase of land rights there is a reciprocal legal relationship between the seller and the buyer, where each party has rights and obligations. The Seller is entitled to the payment of the price of the object being traded and is obliged to submit the rights to the sale object to the buyer. The buyer has the right to receive the object of sale and is obliged to pay the promised and agreed-upon price.

In the making of the deed of sale and purchase as an authentic proof of legal action for the parties, the deed of sale and purchase made by the PPAT should be made and signed by the parties (Seller and Buyer) and witnesses in front of the ppat concerned. Provisions on the presence of the parties in the making of deed by PPAT are also stipulated in Article 101 of the Regulation of the Minister of Agrarian State / Head of National Land Agency No. 3 of 1997 concerning The Implementation Provisions of Government Regulation No. 24 of 1997 concerning Land Registration.

The reading of this deed is intended so that the deed can be understood by the parties concerned which then after the parties understand the contents of the deed and agree, the parties sign the deed of sale and purchase as a sign of agreement of the parties. Regarding the signature in this deed, Salim HS., in his book "Technique of Making Deed One (Theoretical Concept, Notary Authority, Form and Minuta Deed)", states that: "The meaning of the signature in the deed is to determine the validity of legal acts made by the parties or as set forth in the deed". 1

In the process of transfer of land rights there is a lot of negligence or deliberateness by PPAT with the intention of benefiting one party or even benefiting ppat itself, it does not close the possibility that a PPAT will participate in the problems arising for the parties who use their services in making authentic deed related to the transfer of land rights and Property Rights to Flat Units.

The philosophical foundation of the establishment of the PPAT profession is to realize the guarantee of legal certainty, order, and legal protection that is based on truth and justice, especially regarding the transfer of land rights and property rights to the Flats Unit. A PPAT must be able to provide assurance of certainty and legal

\footnotetext{
${ }^{1}$ Salim HS., Teknik Pembuatan Akta Satu (Konsep Teoretis, Kewenangan Notaris, Bentuk Dan Minuta Akta), Edisi 1, Cetakan Kedua, PT.
} Rajagrafindo Persada, Jakarta, 2016, (selanjutnya disebut Salim HS. I), hlm. 85. 
protection to the public who use its services through the deed it makes.

Therefore, PPAT as a public official authorized to make authentic deed in the field of land must act honestly and comply with the prevailing laws and codes of professional ethics. If there is a deed made by PPAT in question by interested parties, then the ppat that is in question can be held accountable and sanctioned.

Legal products produced by a PPAT are authentic deed. An authentic deed made by a PPAT essentially contains formal truth in accordance with what the parties inform the PPAT concerned. However, a PPAT has an obligation to include that what is contained in the deed has been fully understood and in accordance with the will of the parties, namely by reading it so that it becomes clear the contents of the deed made. As such, the parties may freely decide whether or not to approve the contents of the deed to be signed.

Authentic deed made by PPAT has perfect evidentiary power, meaning no more supporting evidence is needed and authentic deed is considered correct because it is made by public officials whose legality has been ensured. Deed made by or before PPAT in Indonesia has the power of proof formil, materiel, and for certain legal acts also have the power of execution. This is because the deed contains elements of ppat testimony concerned with the element of when, where and who committed a legal action. However, not all deed made by PPAT has perfect proof power (authentic).

As stated by Sudikno Mertokusumo, in his book "Indonesian Civil Procedure Law" gives a view on authentic deed, which basically states that an authentic deed is not enough if the deed is made by or before officials only, but the way to make the deed must be in the provisions stipulated by the law. ${ }^{1}$

This means that there are some conditions caused by violations, either from the PPAT itself or the parties, which can make the deed lose its authenticity. A PPAT is responsible if in carrying out the duties of his office there is an error. In the event that the ppat error causes harm to the person who requested ppat services as a public official authorized in the creation of an authentic deed, then he must be responsible for the deed he made.

Related to this, in the Decision of mataram District Court No. 204/Pdt.G/2017/PN.Mtr, it is known that a land sale and purchase transaction between Soekirman and Fanny Djohan has been conducted, in the form of:

a. A plot of land with SHM Number: 1921/Batu Layar based on The Deed of Sale and Purchase Number: 153/2012 on May 10, 2012.

b. A plot of land with SHM Number: 2171/Batu Layar based on The Agreement of Sale and Purchase Bond

No. 27 dated October 31, 2008 and Deed of Sale and Purchase Number: 206/2010 on August 25, 2010.

Based on the court's decision, it is known that the original owners of these areas of land who at the same time acted as "sellers" were the same person who was Soekirman's brother. The fact that it turns out that based on the Death Certificate Number: 73/LKLB/V/2015, dated May 13, 2015, signed by the Head of The New Pagesangan And Lurah Pagesangan Environment, it is known that Soekirman as a seller on the Deed of Sale and Purchase was deceased on June 19, 2009. Thus, it is known that the seller has died before the signing of the Deed of Sale and Purchase Number: 153/2012 on May 10, 2012.

Based on the legal events as described above, it is known that the implementation of the making of deed by the PPAT in question is very different between the rules that must be obeyed and the process of implementation of responsibilities carried out by the PPAT, especially in the signing and making of deed, which has been expressly explained in Article 101 of the Regulation of the Minister of Agrarian State / Head of national land agency No. 3 of 1997 concerning the Implementation Provisions of Government Regulation No. 24 of 1997 concerning Land Registration jo. Article 52 regulation of the Head of the National Land Agency of the Republic of Indonesia Number 1 of 2006 concerning the Implementation Provisions of Government Regulation No. 37 of 1998.

PPAT in carrying out the task of making a deed, must be attended by the parties in the relevant legal action or its proxies in accordance with the laws and regulations. It is very clear that in the implementation of its position, the PPAT concerned ignores the prevailing laws and regulations. The professional code of conduct of PPAT is also not carried out especially in terms of upholding the basis of the state and applicable laws and working responsibly, independently, honestly, impartially.

Based on the description on the background above, the problems in this study are as follows:

1. What is the validity of the deed of sale and purchase made by ppat signed after one of the parties dies?

2. What is the responsibility of the Land Deed Pambuat Official to the deed he made signed after one of the parties passed away?

\section{Library Overview}

\section{Legal Protection Theory}

The profession of a PPAT as a public official authorized to make authentic deeds in the land sector must comply with the applicable laws and regulations. The philosophical basis for the establishment of the PPAT profession is

\footnotetext{
${ }^{1}$ Sudikno Mertokusumo, Hukum Acara Perdata Indonesia, Edisi Kedelapan, Cetakan Pertama, Liberty, Yogyakarta,2009, (selanjutnya disebut Sudikno Mertokusumo I), hlm. 157.
} 
to ensure legal certainty, order, and legal protection with the core of truth and justice, especially regarding the transfer of land rights and Ownership Rights to Flat Units carried out through legal actions. A PPAT must be able to provide guarantees of legal certainty and protection to people who use his services through the deed he made.

The importance of the role of PPAT in helping to create legal certainty and legal protection for the community is more preventive in nature, namely preventing problems from occurring by issuing an authentic deed made before him related to the legal status, rights and obligations of a person in law which serves as evidence of the transfer of land rights or Ownership of Flat Units. The deed made by or before the PPAT can be authentic evidence in providing legal protection to the parties and those with an interest in the deed regarding the certainty of the event or the certainty of the legal action.

\section{Legal Certainty Theory}

This teaching of legal certainty comes from dogmatic juridical teachings which are based on the positivist school of thought in the legal world, which tends to see law as something autonomous, independent, because for adherents of this thought, law is nothing but a collection of rules. For adherents of this school, the purpose of law is nothing but guaranteeing the realization of legal certainty. Legal certainty is realized by law with its nature which only makes a general rule of law. The general nature of the rule of law proves that the law does not aim to achieve justice or benefit, but solely for certainty.

The PPAT profession as a public official authorized to make authentic deeds in the land sector, must be able to provide guarantees of legal certainty and protection through the legal products it produces (authentic deeds made) to the parties who use its services.

As explained in the section on legal protection theory above, the deed made by PPAT as authentic evidence which is used as the basis for registering the transfer of land rights or property rights to flat units, must be able to provide certainty of events or certainty of legal actions in the deed.

\section{Legal Liability Theory}

The theory of legal responsibility is a theory that analyzes the responsibility of legal subjects or actors who have committed acts against the law or criminal acts that cause harm or disability, or the death of another person.

The emergence of responsibilities in the civil sector is due to legal subjects not carrying out achievements and/or committing acts against the law. Achievement of legal subjects in the form of doing something, doing something, and not doing something. If the legal subject does not carry out his achievements, then he can be sued or be asked for civil liability, namely carrying out the achievements and/or paying compensation to the legal subjects who are harmed.

Responsibility theory explains that a person is legally responsible for a certain act that has been done or that he bears legal responsibility. This means that he is responsible for a sanction in the event that the act committed is contrary.

\section{Transfer of Land Rights Through Sale and Purchase}

The transfer of land rights is the transfer of land rights from the old right holder to the new right holder according to the provisions of the applicable laws and regulations. In national land law, the transfer of land rights is carried out in 2 (two) ways, namely through legal events (switching) and legal actions (transferring).

To better understand the meaning of buying and selling, it can be seen from the basis for the formation of the UUPA (National Agrarian Law), which is based on customary law, as stated in Article 5 of Law Number 5 of 1960 concerning Basic Regulations of Agrarian Principles, namely:

The agrarian law that applies to earth, water and space is customary law, as long as it does not conflict with national and state interests, which is based on national unity, with Indonesian socialism and with the regulations contained in this Law and with other laws and regulations., everything with due regard to elements that rely on religious law.

Thus, it can be said that the transfer of land rights through buying and selling is a legal act in the form of transferring land rights by the seller to the buyer voluntarily (deliberately) forever and is entitled to receive payment as a price. At the same time, the buyer voluntarily (deliberately) submits payment as a price to the seller and is then entitled to receive rights to the land which is the object of the sale and purchase.

\section{Land Titles Registrar}

Land Deed Making Officer (PPAT) is a position established based on the provisions of Article 19 PP Number 10 of 1961 concerning Land Registration

The position of PPAT is regulated separately through Government Regulation Number 37 of 1998 concerning the Regulation of the Position of Land Deed Maker Official.

Deed 
Deed is a writing that is deliberately made to be used as evidence of an event and signed by the party who made it. Deeds are divided into authentic deeds and private deeds.

The PPAT deed is made in the form determined by the minister. All types of PPAT deed are given one serial number which repeats itself at the beginning of the calendar year. The PPAT deed is made in its original form in 2 (two) sheets, namely: the first sheet, 1 (one) original copy is kept by the PPAT concerned; and the second sheet, as many as 1 (one) original or more copies according to the number of land rights or property rights to the apartment unit which is the object of legal action in the deed, which is submitted to the Land Office for registration purposes, or in the case of the deed concerning the granting of power of attorney. imposes mortgage rights, is submitted to the power of attorney for the basis of making a deed of granting mortgages, and a copy can be provided to interested parties. ${ }^{1}$

\section{RESEARCH METHOD}

The type of research used in this research is juridical-normative. According to Zainudin Ali, "Normative juridical legal research refers to legal norms contained in laws and regulations and court decisions, as well as legal norms that exist in society." (Ali, 2011) The approach method used in this research is the Legislative Approach; Conceptual Approach; Case Approach; and analytical approach;

The types of legal materials that the author uses are legal materials sourced from literature studies with 2 (two) kinds of legal materials that can be used by the authors, namely Primary Law materials, which consist of statutory regulations, Secondary Law materials in the form of all publications on the law that are not official documents that are considered relevant to answer the problems in this research. And the author will also conduct interviews and dialogue with several parties, especially PPAT and Lecturers to express opinions related to legal issues in this research.

The technique of collecting legal materials used in this research is literature study. The literature study is carried out by a selection process, by collecting legal materials that are considered related to the problems discussed in this study and then classifying the legal materials that have been collected. The analysis of legal materials in this research is descriptive. Meaning, to determine the content or meaning of the rule of law that is used as a reference in this study to resolve legal issues that are the object of study.

\section{DISCUSSION}

\section{VALIDITY OF THE SALE AND PURCHASE DEED MADE BY PPAT SIGNED AFTER THE SELLER DIES}

\section{A. Position Case Based on Mataram District Court Decision Number: 204/Pdt.G/2017/PN.Mtr}

In the Decision of Mataram District Court Number: 204/Pdt.G/2017/PN.Mtr, the lawsuit between Erni Yohana who sued Fanny Djohan and the Head of the local Land Office, it is known that over 2 (two) areas of disputed land that have been issued as property rights are:

1. SHM Number: 1921/Batulayar dated February 17, 2005 on a plot of land covering an area of 23,334 M2; and

2. SHM Number: 2171/Batulayar dated September 5, 2008 on an area of 4,028 M2.

Each of these land areas is registered in the name of Soekirman which has then been reversed into the name of Fanny Djohan at the West Lombok Regency Land Office. The process of renaming is based on:

1. SHM Number 1921/Batu Layar dated February 17, 2005, Letter of Measurement Number: 1163/BTL/2005, dated February 7, 2005 for a plot of land covering an area of 23,334 M2, which was originally registered in the name of Soekirman and later became Fanny Djohan based on the "Deed of Sale and Purchase" Number :153/2012, dated May 10, 2012.

2. SHM Number 2171/Batu Layar dated September 5, 2008, Letter of Measurement Number: 1410/BTL/2008, dated August 30, 2008, for a plot of land covering an area of 4,028 M2, which was originally registered under the name of Soekirman and later became Fanny Djohan based on the "Sales Agreement Purchase" Number 27 dated 31 October 2008 and "Deed of Sale and Purchase" Number : 206/2010, 25 August 2010.

The fact is that based on the "Death Certificate" Number: 73/LKLB/VI/2015, dated May 13, 2015, which was signed by the Head of the Pagesangan Baru Environment and the Pagesangan Village Head, which basically stated that Soekirman had died on Friday dated June 19, 2009 at the Mataram General Hospital, which was caused by illness. With the death certificate, it is very unlikely that Soekirman, who has died, can sign the sale and purchase deed.

In the process of transferring land rights, if a person whose name is recorded on the certificate has died, then in order to be able to transfer the object of the land through buying and selling, the transfer of rights through inheritance must first be carried out to the heirs. As stipulated in Articles 832 and 833 of the Civil Code which

\footnotetext{
${ }^{1}$ Pasal 21 Peraturan Pemerintah Nomor 37 Tahun 1998 Tentang Peraturan Jabatan Pejabat Pembuat Akta Tanah.
} 
states that:

Article 833 paragraph (1) of the Civil Code:

All the heirs automatically by law obtain ownership rights to all goods, all rights and all receivables of the deceased.

Article 832 of the Civil Code

According to the law, those who have the right to become heirs are blood relatives, both legal and out of wedlock and the husband or wife who has lived the longest, all according to the regulations listed below.

Based on the description of legal facts as described above, shows that there has been the creation of a Deed of Sale and Purchase of land rights by the ppat in question where the deed is signed after the seller dies.

\section{B. The Validity of The Sale and Purchase Act Made By Ppat Signed After the Seller Dies}

\section{Authentic Deed According to Civil Code}

In the provisions of Article 1867 of the Civil Code it is stated that proof by writing is done with authentic deed and deed under hand. Furthermore, in Article 1868 of the Civil Code mentioned the definition of authentic deed, namely:

An authentic deed is a deed made in a form prescribed by law by or before the public official authorized to do so at the place where the deed is made

One of the elements that is deemed necessary to be added is that the deed must have perfect evidentiary power because in making an authentic deed by or before an authorized official, it means that what the official said is something that he sees is considered true before him. This is considered so because in making the deed, the official concerned is bound by the terms and conditions in the laws and regulations, so that it is considered sufficient as a guarantee of the trustworthiness of the official, so the legal actions contained in the deed are sufficient. evidenced by the deed itself. Thus, the deed can be considered to have been made in accordance with the facts as seen by the official concerned until it can be proven otherwise.

Based on the provisions of Article 1870 of the Civil Code, the power of proof of an authentic deed has perfect evidentiary power, meaning that it has the power of outward, formal and material proof.

An authentic deed in order to have perfect evidentiary power must contain all elements of evidence. R. Soegondo Notodisoerjo in his book "Notarial Law in Indonesia, An Explanation", states the elements of evidence that must be possessed in an authentic deed, in the form of: ${ }^{1}$

a. Writing;

b. Witnesses;

c. conjectures;

d. Recognition; and

e. Oath

Writing as written evidence or commonly known as a letter is anything that contains reading signs intended to pour out one's heart or to convey one's thoughts and be used as evidence. Thus, everything that does not contain reading signs or even though it contains reading signs but does not contain thoughts, is not included in the meaning of written evidence. Something like a photo or picture does not contain reading signs or thoughts, as well as a floor plan or map, even though it contains reading signs, but does not contain a person's thoughts or feelings, cannot be categorized as written evidence (letters). However, it can be used as an object to convince something.

In addition to the things mentioned above, to be classified as a deed, the letter must be signed, this is in accordance with the provisions in Article 1869 of the Civil Code. The requirement for a signature in a deed aims to distinguish one deed from another. So the function of the signature in the deed is to characterize a deed. According to Salim HS., in his book "Deed Making Techniques (Theoretical Concepts, Notary Authority, Form and Minutes of Deeds)" states that:

"The meaning of the signature in the deed is to determine the validity of the legal action made by the parties or as set forth in the deed. The signatures of the parties, witnesses and notaries are only set forth in the minuta deed". 2

The equivalent of a signature on an underhand deed is a fingerprint (fingerprint or thumbprint) which is confirmed by a dated statement by a notary or other official appointed by law, stating that he knows the person who affixed the fingerprint. the finger or person is introduced to him, and that the contents of the deed have been read and explained to him, then the fingerprint is affixed to the deed in the presence of the official.

Thus, it can be said that if a deed has been signed or given a fingerprint (thumbprint) by the parties, then the deed is considered valid and can be used as evidence in court, because if the deed has been signed by the parties

\footnotetext{
${ }^{1}$ R. Soegondo Notodisoerjo, Hukum Notariat Di Indonesia, Suatu Penjelasan, Rajawali, Jakarta, 1982, hlm. 6.

${ }^{2}$ Salim HS. I, OP. Cit., hlm. 85.
} 
then The signature is considered a sign of the agreement of the parties who made it and agreed to the contents of the deed.

Proof in writing in court can be done with authentic writings (authentic deeds) or by writing (deeds) under the hand. In proof by writing under the hand, there are writings made with the aim not as evidence, but can be used as evidence. If something like this happens, of course, it must also be supported by other evidence in order to have the power of proof.

An underhand deed is a deed of free form and is made without the assistance of a public official. Sudikno Mertokusumo in his book "Indonesian Civil Law", states that: "A private deed is a deed that is intentionally made for proof by the parties without the assistance of an official. So it is solely made between the interested parties. (Mertokusumo, 2009)

Thus, it can be seen that the basic difference between an authentic deed and a private deed is the proving power of the deed. Authentic deeds have perfect evidentiary power. Meanwhile, if an underhand deed is used as evidence in court, it must be supported or linked to other evidence so that the deed can have evidentiary value in court.

\section{Validity of Sale and Purchase Act Made by PPAT Signed After Seller Dies}

The deed of sale and purchase made by PPAT to be considered as an authentic deed must meet the requirements set out in the laws and regulations and must be made by the authorized official where the deed was made. In carrying out a legal act, especially in the sale and purchase agreement of land rights, the agreement must meet the general requirements of an agreement, as determined in the applicable laws and regulations, including starting from the conditions for the validity of an agreement, the conditions specified by the parties themselves, up to the requirements for re-registering the name of the certificate as a result of the legal action.

In the practice of making a deed of sale and purchase by PPAT there are often deviations from the applicable rules caused by the situations or conditions in the sale and purchase carried out. These conditions can come from the parties facing the PPAT or situations faced in the future. Situations or conditions like this can make the PPAT concerned have no other choice but to ignore the procedure for making a deed of sale and purchase in accordance with the laws and regulations.

The form of a sale and purchase agreement is a series of rights and obligations of both parties, which are mutually promised, namely between the seller and the buyer. The seller promises to deliver an item and is entitled to receive the price of the item and the buyer promises to deliver the price of the item and has the right to receive the item that is the object of sale and purchase. The sale and purchase agreement is regulated in Article 1457 to Article 1540 of the Civil Code.

Buying and selling can be said as a form of agreement that gives birth to rights and obligations between the seller and the buyer to provide something in the form of delivery of the objects sold by the seller to the buyer and the buyer submits the price to the seller as a form of reciprocity for the legal action.

As a form of agreement, buying and selling must meet the legal requirements of an agreement as stipulated in Article 1320 of the Civil Code, namely:

For the validity of an agreement, four conditions are required:

a. Agree on those who bind themselves;

b. The ability to make an engagement;

c. A certain thing;

d. A lawful reason.

In addition to having to fulfill the legal requirements of an agreement, in carrying out the sale and purchase of land rights, the seller and buyer must register the transfer of land rights to the local Regency/Municipal Land Office in order to achieve orderly land administration. One of the requirements for registering the transfer of land rights is the existence of a deed of sale and purchase made by the authorized PPAT.

Based on the provisions of Article 37 of Government Regulation Number 24 of 1997 concerning Land Registration, it indicates that for the purpose of registering the transfer of land rights or Ownership Rights to Flat Units at the Regency/City Land Office, the sale and purchase of land rights or Ownership Rights to Flat Units must evidenced by the PPAT deed. In certain circumstances, the Head of the Regency/City Land Office may register the transfer of rights to a parcel of land with Hak Milik, where the parties are Indonesian citizens as evidenced by a deed not made by the PPAT, but the level of truth of the deed is considered sufficient to register the transfer of the right in question. .

After all the requirements by the parties are considered to have been fulfilled, then the PPAT concerned makes the deed of sale and purchase. Based on the provisions of Article 21 of Government Regulation Number 37 of 1998 concerning Position Regulations for Land Deed Making Officials, it is determined that the PPAT Deed is made in the form determined by the minister, although the form has been determined by the minister, there are many opinions which state that the Land Deed Official Deed is still an authentic deed. . All types of PPAT deed are given one serial number which repeats itself at the beginning of the calendar year. The PPAT deed is made in the original form in 2 (two) sheets, namely the First Sheet, one copy is kept by the PPAT 
concerned; and Second Sheet, in one or more copies according to the number of land rights, ownership rights to the apartment unit which are the object of legal action in the deed, which is submitted to the local Land Office for registration purposes, or in the case of the deed concerning the granting of power of attorney to impose mortgage rights, submitted to the power of attorney for the basis for making the deed of granting mortgage rights, and a copy can be provided to interested parties.

Before the deed of sale and purchase made by the PPAT is signed, the deed of sale and purchase must first be read/explained by the PPAT concerned to the parties in the deed.

With the Deed of Sale and Purchase by PPAT, at that time there has been a transfer of land rights or Ownership Rights to Flat Units from the holder of the rights who were originally the seller to another party as the buyer. However, if it is only with the deed of sale and purchase, then the transfer of rights is only known by the Seller, Buyer, Witnesses, and PPAT only. So that other parties can also know about the sale and purchase, the sale and purchase must be registered at the local Regency/City Land Office because land registration in Indonesia is open. By registering the transfer of rights at the Regency/City Land Office, the principle of publicity in land registration is fulfilled, namely that everyone can find out the physical data of the land in the form of location, size, land boundaries, and juridical data in the form of the subject of the right holder, the status of the right, as well as the transfer of land rights or Ownership Rights to the respective Flats at the local Regency/Municipal Land Office.

After the deed of sale and purchase is signed by the parties, then the deed of sale and purchase is not later than 7 (seven) working days after the day of signing the deed, it must be registered at the local Regency/Municipal Land Office.

In the provisions of Article 40 of the Government Regulation Number 24 of 1997, it is not stated if the deed of sale and purchase which has been signed by the parties has not been registered with the Land Office after the 7 (seven) working day limit. Related to this, in the provisions of Article 103 paragraph (7) Regulation of the State Minister of Agrarian Affairs/Head of the National Land Agency Number 3 of 1997 concerning Provisions for the Implementation of Government Regulation Number 24 of 1997 concerning Land Registration.

Thus, it is clear that even though the sale and purchase deed made by the PPAT has been signed but has not been registered at the land office after 7 (seven) working days from the day the sale and purchase deed was signed, the PPAT concerned can still register the legal act of transferring rights to the land. at the local Regency/City Land Office. Because of the provisions of Article 103 paragraph (7) of the Regulation of the Minister of State for Agrarian Affairs/Head of the National Land Agency Number 3 of 1997, the Head of the Regency/City Land Office concerned is still obliged to accept the registration of the act of transferring land rights or Ownership Rights to Flat Units that have been evidenced by a deed made by PPAT.

\section{Legal Consequences of The Sale and Purchase Act Made by PPAT Signed After the Seller Dies}

The obligation of a PPAT is to know all the laws and regulations and norms that apply in Indonesia and to know the legal regulations that apply to the parties who appear before him to make a deed. This is very much needed by PPAT in carrying out his position so that the deed he makes does not lose its authenticity as perfect evidence. However, in reality a PPAT may make a mistake in making the deed which can result in losses for the parties in the deed.

If there is a deed made by the PPAT that is disputed by the parties or other interested parties, then the settlement must be based on the cancellation and cancellation of the PPAT deed in question as authentic evidence. Errors that occur in the deed will be decided by the judge when the deed is filed in court.

In the Decision of the Mataram District Court Number: 204/Pdt.G/2017/PN.Mtr, it is known that the "Deed of Sale and Purchase" Number: 153/2012, dated May 10, 2012, which became the basis for the "transfer of name" Certificate of Ownership (SHM) Number : 1921/Batu Layar, made by PPAT domiciled in West Lombok. In the decision, it is known that there has been a transfer of land rights through a sale and purchase between Soekirman and Fanny Djohan based on the Sale and Purchase Deed Number :153/2012, dated May 10, 2012, against SHM Number: 1921/Batu Layar. Meanwhile, Soekirman, the owner of the original plot of land as the seller in the two deed of sale and purchase, died on Friday, June 19, 2009 at the Mataram General Hospital, as evidenced by the Death Certificate Number: 73/LKLB/VI/2015, dated May 13, 2015, which was signed by the Head of the New Pagesangan Environment and the Pagesangan Village Head.

From the facts mentioned above, it is known that in the making of the Sale and Purchase Deed by the relevant PPAT the seller was not attended, thus it can be said that there was never an agreement between the seller and the buyer. Therefore, it can be said that the PPAT concerned has included information that is not in accordance with the original situation in the making of the Sale and Purchase Deed. Because, if a holder of land rights has died, then the rights to the land must be transferred to the heirs first, then the rights to the land can be transferred to other parties through buying and selling. This is in accordance with the provisions as stipulated in Article 833 paragraph (1) jo. Article 832 paragraph (1) of the Civil Code, which states that:

Article 833 paragraph (1) of the Civil Code:

All the heirs automatically by law obtain ownership rights to all goods, all rights and all receivables of the 


\section{deceased.}

Article 832 of the Civil Code

According to the law, those who have the right to become heirs are blood relatives, both legal and out of wedlock and the husband or wife who has lived the longest, all according to the regulations listed below.

In the event that neither the blood family nor the one who has lived the longest between husband and wife are present, then all the assets left by the deceased will become the property of the State, which the authorities will pay off all debts, only the price of the inheritance is sufficient for that.

Thus, before the sale and purchase of land rights is carried out, inheritance must first be carried out, the process of which needs to be registered at the local Regency/City Land Office. Because, in the transfer of land rights or Property Rights to Flats, only the right holder is authorized to transfer, because basically a person cannot sell an item that is not his right, as stipulated in Article 1471 of the Civil Code.

All deeds which are under the authority of PPAT to make them are authentic deeds that have perfect proof characteristics, including the deed of sale and purchase. Therefore, PPAT in making a deed must be careful in all aspects including how to make the correct deed so that it meets the requirements to become an authentic deed. The contents of the deed must also be as it is, do not contain something that is engineered because it can cause problems in the future.

Although the information submitted in the deed is the responsibility of the parties, the PPAT must remain careful in receiving and processing information from the parties concerned. The PPAT concerned must still conduct research on the truth of the information submitted by the parties.

Before making the deed of sale and purchase by the PPAT, the PPAT concerned asks the seller and the buyer to show the necessary documents as a condition for making the deed. The documents that need to be prepared before making the deed of sale and purchase by PPAT.

One of the conditions that need to be considered before making the deed by the PPAT concerned is that the transfer of land rights must be paid off, because a PPAT is not allowed to make a deed of sale and purchase in stages (in installments). As stated by Wayan Parta, a PPAT in West Lombok, in an interview the author conducted, who revealed that:

"PPAT should not make a deed of gradual sale and purchase. If the trade is gradual means a notary who has authority. Because of the principle of ppat deed, buying and selling based on the principle of customary law, kontan, real and cash. Before the parties sign the deed, the trade must be paid off."1

He also added that: "This deed (Deed of Sale and Purchase made by PPAT) has 2 functions, namely for proof of payment in full and for the transfer of rights which were originally on behalf of the seller to the buyer." Thus, it is known that if the sale and purchase deed made by a PPAT has been signed by the parties, it means that the sale and purchase of land rights has been paid in advance, because the sale and purchase deed made by PPAT contains the principles of customary law, namely cash, real and cash

After the deed is made then the deed is read and explained by the PPAT concerned. The reading of this deed must be attended by the Parties and their witnesses. This is as stipulated in Article 101 of the Regulation of the State Minister of Agrarian Affairs/Head of the National Land Agency Number 3 of 1997 concerning Provisions for the Implementation of Government Regulation Number 24 of 1997 concerning Land Registration, which stipulates that:

(1) The making of the PPAT deed must be attended by the parties carrying out the legal action concerned or the person authorized by him/her with a written power of attorney in accordance with the applicable laws and regulations.

(2) The making of the PPAT deed must be witnessed by at least 2 witnesses who according to the provisions of the applicable laws and regulations meet the requirements to act as witnesses in a legal act, who testify, among others, regarding the presence of the parties or their proxies, the existence of documents indicated in the making of the deed, and the legal action has been carried out by the parties concerned.

(3) The PPAT is obligated to read the deed to the parties concerned and provide an explanation of the content and purpose of making the deed, and the registration procedure to be followed up in accordance with the applicable provisions.

After the signing of the deed by the parties, witnesses, and ppat concerned, then within no later than 7 (seven) working days after signing, the legal action of transfer of rights to the land must have been registered with the local District / City Land Office. In Article 40 paragraph (1) of Government Regulation No. 24 of 1997 concerning Land Registration, it is determined that:

No later than 7 (seven) working days from the date of signing of the relevant deed, PPAT shall submit the deed it makes along with the relevant documents to the Land Office to be registered.

Related to the period of 7 (seven) days, article 103 paragraphs (7) and (8) Regulation of the Minister of Agrarian State / Head of national land agency of the Republic of Indonnesia No. 3 of 1998 concerning the

\footnotetext{
${ }^{1}$ Wawancara dengan Wayan Parta, PPAT berkedudukan di Lombok Barat, pada tanggal 24 Mei 2021.
} 
Provisions of Implementation of Government Regulation No. 24 of 1997 concerning Land Registration, which states that:

(1) The registration of the transfer of rights due to the transfer of rights as evidenced by the PPAT deed must also be carried out by the Head of the Land Office in accordance with the applicable provisions even though the submission of the PPAT deed exceeds the 7 (seven) day time limit as referred to in paragraph (1).

(2) In the case as referred to in paragraph (7) the PPAT concerned is notified of the violation of the provisions on the deadline for the submission of the deed.

Thus, even though the deed made by PPAT has passed the 7 (seven) day time limit, it should still be received by the Regency/City Land Office as proof of the transfer of land rights or Ownership Rights to Flat Units, provided that the Head of the Office Regency/Municipal Land Affairs give a warning to the PPAT concerned regarding the delay in submitting the registration for the transfer of land rights.

The official making the land deed is a position born based on the laws and regulations established by the authorized institution. In carrying out his position as a public official, a PPAT is required to act honestly, independently, impartially and work with a full sense of responsibility. A PPAT in carrying out his position, of course, must protect the interests of the parties so that everyone who appears before him in order to make a deed as evidence of the legal action he has committed does not feel harmed.

In making a deed of sale and purchase by PPAT which is signed after the seller dies, of course it will have an impact on the strength of the proof of the deed. The power of proof of the deed can be reduced to a deed under the hand or can even be canceled or null and void by law. With the decrease in the strength of the proof of the deed, it can harm the parties. As in the Mataram District Court Decision Number: 204/Pdt.G/2017/PN.Mtr., in which the Sale and Purchase Deed Number: 153/2012 dated 10 May 2012, which is used as the basis for the transfer of land rights to SHM Number: 1921 Batu Layar can be canceled by a judge because the legal action was carried out after the seller died. With the cancellation of the legal action in the sale and purchase deed, the deed loses its binding power as stipulated in Article 1338 of the Civil Code, that:

All legally made agreements apply as law to those who make them.

According to Wayan Parta, a PPAT in West Lombok, gave an opinion on the deed of sale and purchase in the case, which argued that:

"I think the deed will come down under the hand, the second, meaning that because the deed under the hand means contrary to the provisions of PP 24 year 1997. Therefore, it can be canceled as long as there is an application to the court. Then if the transfer of rights is canceled, it means that the certificate goes back to the beginning."1

In Article 1868 of the Civil Code, it is stated that:

An authentic deed is a deed in a form prescribed by law, made by or in the presence of public officials in power thereto in the place where the deed is made.

Referring to article 1868 of the Civil Code, the deed of sale and purchase mentioned in the Decision of the Mataram District Court Number: 204/Pdt.G/2017/PN.Mtr., certainly cannot be said as an authentic deed, because the making of the deed is not in accordance with the provisions of the laws and regulations, namely:

a. Article 1320 of the Civil Code;

b. Article 38 Government Regulation Number 24 of 1997 concerning Land Registration;

c. Article 101 Regulation of the State Minister of Agrarian Affairs/Head of the National Land Agency Number 3 of 1997 concerning Provisions for the Implementation of Government Regulation Number 24 of 1997 concerning Land Registration;

d. Article 22 Government Regulation Number 37 of 1998 concerning Position Regulations for Land Deed Making Officials as amended by Government Regulation of the Republic of Indonesia Number 24 of 2016 concerning Amendments to Government Regulations Number 37 of 1998 concerning Position Regulations for Land Deed Makers;

e. Article 52 Regulation of the Head of the National Land Agency Number 1 of 2006 concerning Provisions for the Implementation of Government Regulation Number 37 of 1998 concerning the Regulation of the Position of Land Deed Maker Officials.

Thus, the Sale and Purchase Deed Number: 153/2012 dated May 10, 2012, which was used as the basis for the transfer of land rights to SHM Number: 1921/Batu Layar in the Mataram District Court Decision Number: 204/Pdt.G/2017/PN. Mtr., cannot be treated as an authentic deed that has perfect evidentiary power, because the making of the deed is contrary to the applicable laws and regulations. If it refers to the legal requirements of the agreement as specified in Article 1320 of the Civil Code, then the agreement on the transfer of land rights does not meet the subjective requirements of an agreement, namely the agreement of the parties to the agreement.

If the agreement of the parties is not fulfilled, the agreement on the transfer of land rights can be canceled.

${ }^{1}$ Wawancara dengan Wayan Parta, PPAT berkedudukan di Lombok Barat, pada tanggal 24 Mei 2021. 
This means that the party who feels aggrieved can apply for the cancellation of the agreement to the court. After the judge's decision stating that the sale and purchase deed is void, it will have an impact on the rights transfer agreement made by the parties. The deed of sale and purchase that has been canceled by the judge cannot be used as the basis for registering the transfer of transfer of land rights at the local Regency/Municipal Land Office. So that the land rights with SHM Number: 1921/Batu Layar will automatically return to the property of the seller and become the rights of the heirs of Soekirman as the seller in the deed of sale and purchase.

\section{RESPONSIBILITY OF THE LAND DEED PAMBUAT OFFICIALS TO THE DEED MADE BY HIM SIGNED AFTER ONE OF THE PARTIES DIED}

Based on the theory of responsibility, in this case it is associated with the responsibility of a PPAT for the deed he made which causes harm to one of the parties due to non-fulfillment of the subjective conditions of the agreement as specified in Article 1320 of the Civil Code. In making an authentic deed regarding a legal action of the parties, a PPAT must be ready to bear all losses for the parties if the loss is caused by a deed made by the PPAT concerned.

The responsibility that is asked to PPAT is not only in the narrow sense of making the deed, but also in a broad sense, namely the responsibility at the time of making the deed and the responsibility at the time of postsigning the deed. When a PPAT makes a mistake in making an authentic deed that causes harm to others as a result of his mistake, the PPAT concerned can be held accountable, either civilly, criminally, or administratively.

In the Decision of the Mataram District Court Number: 204/Pdt.G/2017/PN.Mtr, namely the Deed of Sale and Purchase Number: 153/2012, dated May 10, 2012, which was made and signed after Soekirman as the Seller died, it can be said that the making of the deed the sale and purchase does not meet the conditions for the validity of the agreement, namely the subjective requirements regarding the agreement of the parties as specified in Article 1320 of the Civil Code. So that the legal actions described in the deed can be canceled if there is an application to the judge. With the cancellation of the judge, the agreement is no longer binding on the parties as stipulated in Article 1338 of the Civil Code.

In addition to not meeting the legal requirements of an agreement, the making of the sale and purchase deed by the PPAT concerned is not in accordance with the provisions of the applicable laws and regulations, namely, among others:

a. Article 38 Government Regulation Number 24 of 1997 concerning Land Registration;

b. Article 101 Regulation of the State Minister of Agrarian Affairs/Head of the National Land Agency Number 3 of 1997 concerning Provisions for the Implementation of Government Regulation Number 24 of 1997 concerning Land Registration;

c. Article 22 Government Regulation Number 37 of 1998 concerning Position Regulations for Land Deed Making Officials as amended by Government Regulation of the Republic of Indonesia Number 24 of 2016 concerning Amendments to Government Regulations Number 37 of 1998 concerning Position Regulations for Land Deed Makers;

d. Article 52 Regulation of the Head of the National Land Agency Number 1 of 2006 concerning Provisions for the Implementation of Government Regulation Number 37 of 1998 concerning the Regulation of the Position of Land Deed Officials. Article 38 of Government Regulation Number 24 of 1997 concerning Land Registration.

Based on the description as described above, the making of the deed of sale and purchase as described in the previous chapter in this study, because it is not in accordance with the applicable provisions, then against the PPAT concerned can be held liable civilly or administratively.

\section{Civil Liability}

Liability in civil law can arise due to legal subjects who do not perform achievements and/or perform legal actions. The achievements of legal subjects in the field of civil law are in the form of giving something, doing something, and not doing something. If the legal subject does not perform his achievements, the legal subject concerned can be held accountable by carrying out his achievements and/or paying compensation to the legal subject who was harmed as a result of the incident

PPAT's civil liability regarding unlawful acts, in this study PPAT's responsibility is associated with the sale and purchase deed he made that did not comply with applicable regulations. The deed made by/or before the PPAT is basically an authentic deed which has perfect proving power regarding the legal actions of the parties. However, the strength of proof of a deed made by PPAT can also be reduced to a private deed if the deed does not meet the elements of an authentic deed as specified in the Civil Code. In Article 1868 of the Civil Code, it can be concluded that the elements of an authentic deed as expressed by Abdul Ghofur Anshori as quoted by Khairulnas and Leny Agustan in his book "Guidelines for Notaries/PPAT in Facing Civil litigation", which states that the elements of an authentic deed are: ${ }^{1}$

\footnotetext{
${ }^{1}$ Abdul Ghofur Anshori dalam Khairulnas dan Leny Agustan, Panduan Notaris/PPAT dalam Menghadapi Gugatan Perdata, hlm. 31.
} 
a. That the deed is made and inaugurated (verleden) in a form according to law;

b. That the deed was drawn up by and before a public official;

c. That the deed was made by and before the official authorized to make it at the place where the deed was made, so the deed must be in the authority of the official who made it.

Legal acts as evidenced by a deed made by PPAT are basically an agreement made between one legal subject and another. So, if a PPAT wants to make a deed as evidence of the legal actions of the parties, then the PPAT concerned should pay more attention to the legal actions of the parties. Because, if the agreement does not meet the requirements determined by the legislation, then the deed made by the PPAT concerned cannot be considered as an authentic deed that has perfect evidentiary power.

Deeds made by or before PPAT have the potential to cause problems or disputes if there are deviations from the legal terms of the land sale and purchase agreement as well as deviations from the procedures for making the deed concerning material requirements (both subject and object) and formal requirements (procedures and requirements). If it is reviewed based on civil law, a PPAT who causes harm to one or both parties in the deed he made, can be held accountable as specified in Article 1365 of the Civil Code which states that:

Every act that violates the law, which causes harm to another person, obliges the person who, because of his fault, issued the loss, to compensate for the loss.

Furthermore, in Article 1366 of the Civil Code, it is stated that:

Everyone is responsible not only for losses caused by his actions, but also for losses caused by negligence or carelessness.

The form of responsibility of a PPAT when associated with its legal product as a public official in the form of an authentic deed regarding the legal actions of the parties, adheres to the principle of responsibility based on an element of fault (based on fault of liability). Because, if a PPAT makes a mistake in making an authentic deed as a perfect evidence, causing harm to the parties concerned about the deed, then the PPAT concerned must be responsible for it.

In making an authentic deed as proof of the transfer of land rights, PPAT must indeed be responsible if there is an error or violation of the deed he made. However, if the element of error or violation occurs from the parties, then the PPAT concerned cannot be held accountable, because the PPAT only records what was conveyed by the parties or appearers to be included in the deed. False information submitted by the parties is the responsibility of the parties themselves.

In the Decision of the Mataram District Court Number: 204/Pdt.G/2017/PN.Mtr, namely the Deed of Sale and Purchase Number: 153/2012, dated May 10, 2012, which was made and signed after Soekirman as the Seller died, it can be said as an act against because the legal action in the deed of sale and purchase does not meet the requirements for the validity of the agreement as stipulated in Article 1320 of the Civil Code regarding the subjective requirements, namely the agreement of the parties. If the sale and purchase deed is canceled by the judge, then the process of changing the name that has been registered based on the sale and purchase deed is also canceled so that it can cause losses to the buyer.

Based on the description above, it can be said that the PPAT concerned has committed an unlawful act that can cause harm to other people, be it the buyer or other people who have an interest in the legal action in the sale and purchase deed. With the fulfillment of all elements of unlawful acts against the case, namely, among others:

a. The existence of deeds;

Making of Deed of Sale and Purchase Number: 153/2012, dated May 10, 2012 as referred to in the

Decision of mataram District Court Number: 204/Pdt.G/2017/PN.Mtr.

b. The existence of an element of error;

The creation of a deed of sale and purchase by the relevant PPAT does not meet the subjective requirements as specified in Article 1320 of the Civil Code and is not in accordance with the procedure of making a deed by / before the PPAT as stipulated in the prevailing laws and regulations.

c.Losses suffered;

With the decision of cancellation from the judge against the deed of sale and purchase, resulting in losses for the buyer in the deed of sale and purchase.

$\mathrm{d}$.There is a causal relationship between error and loss.

Because of an error in the making of the deed of sale and purchase by the PPAT in question resulted in the deed of sale and purchase can be canceled so as to cause losses to the buyer in the deed of sale and purchase.

With the fulfillment of all elements of unlawful acts as formulated in Article 1365 of the Civil Code, then the party who feels aggrieved as a result of the incident can file a civil lawsuit to the court to ask for compensation from the PPAT concerned. In filing a claim for compensation, it is the judge who has the authority to determine how appropriate the party who suffered the loss should be assisted in compensation 
for the loss suffered, even if the party experiencing the loss demands compensation in an inappropriate amount.

The buyer who is harmed by the incident can file a civil lawsuit to the court. Based on the consideration of the judge who is authorized to decide the case, if the PPAT in question is proven to have committed an unlawful act either intentionally or based on an oversight and/or negligence, then the PPAT concerned can be held accountable in the form of payment of compensation to the party who feels aggrieved.

\section{Administrative Responsibility}

The legal product of a PPAT is in the form of an authentic deed as a perfect evidence that can guarantee legal certainty and protection for the parties who use its services. However, sometimes a PPAT makes a mistake so that the deed he makes cannot provide the legal certainty and protection needed by the parties who use his services. If this happens, then the PPAT concerned can be held accountable administratively. Administrative responsibility for a PPAT who violates the provisions of the legislation in carrying out his duties, especially in making authentic deeds in the form of sanctions by the authorized official.

Based on Government Regulation Number 37 of 1998 concerning the Position Regulation of Land Deed Making Officials, PPAT is appointed and dismissed by the minister which in this case is the authority of the Ministry of Agrarian Affairs and Spatial Planning/Head of the National Land Agency. Regarding the dismissal of PPAT, Article 8 paragraph (1) and paragraph (2) of Government Regulation Number 37 of 1998 concerning Position Regulations for Land Deed Maker Officials as amended by Government Regulation Number 24 of 2016 concerning Amendments to Government Regulation Number 37 of 1998 concerning Position Regulations The Land Deed Official, determines that:

(1) PPAT ceased to serve as because:

a) Died;

b) Has reached the age of 65 (sixty-five) years; or

c) Dismissed by the minister in accordance with the provisions of this government regulation.

(2) The age provisions as referred to in paragraph (1) letter b can be extended for a maximum of 2 (two) years until the age of 67 (sixty-seven) years taking into account the health of the concerned.

In carrying out its duties and positions, PPAT is supervised by the minister who in this case is the Ministry of Agrarian and Spatial Affairs / Head of the National Land Agency. This is in accordance with Article 33 of Government Regulation No. 37 of 1998 concerning Regulation of the Office of the Land Deed Official, which states that:

The Minister carries out the development and supervision of the implementation of PPAT duties.

The guidance carried out by this minister is an effort, action and activities carried out by the Minister towards PPAT effectively and efficiently to achieve better ppat quality. Meanwhile, Supervision is a preventive and repressive administrative activity by the Minister that aims to keep the PPAT in carrying out its position in accordance with the provisions of the laws and regulations. ${ }^{1}$

Furthermore, in Article 4 of the Regulation of the Minister of Agrarian and Spatial Affairs / Head of the National Land Agency No. 2 of 2018 concerning the Construction and Supervision of Land Deed Officials, determines that:

(1) Guidance and supervision of PPAT shall be carried out by the Minister.

(2) The guidance and supervision as referred to in paragraph (1) in the regions is carried out by the Head of the BPN Regional Office and the Head of the Land Office.

If the PPAT makes a mistake whether it is intentional, negligence or negligence in making an authentic deed as evidence of the legal actions of the parties so as to cause harm to the parties concerned, by the Head of the local Land Office if the PPAT concerned is proven to have done so, then the Head of the Land Office The Provincial Region or the Head of the Regency/Municipal Land Office where the PPAT is domiciled is authorized to impose sanctions on him.

Administratively PPAT accountability is determined in Article 62 of Government Regulation Number 24 of 1997 concerning Land Registration, which states that:

PPAT which in carrying out its duties ignores the provisions as referred to in Article 38, Article 39 and Article 40 as well as the provisions and instructions provided by the Minister or appointed Officials are subject to administrative action in the form of written reprimand until the dismissal of his position as PPAT, by not reducing the possibility of being sued for damages by the parties who suffer losses resulting from the neglect of such provisions.

Ppat liability is also administratively regulated in Article 8 of the Regulation of the Minister of Agrarian and Spatial Affairs / Head of the National Land Agency No. 2 of 2018 concerning the Construction and Supervision of Land Deed Officials, which states that:

\footnotetext{
${ }^{1}$ Pasal 1 angka 2 dan 3 Peraturan Menteri Agraria Dan Tata Ruang/Kepala Badan Pertanahan Nasional Nomor 2 Tahun 2018.
} 
Supervision of PPAT as referred to in Article 4, may be:

a. supervision of the implementation of PPAT positions; and PPAT.

b. enforcement of the rule of law in accordance with the provisions of the legislation in the field of

The supervision carried out on PPAT as mentioned above, aims to ensure that PPAT has carried out its obligations and positions in accordance with the provisions of the legislation. Supervision carried out by either the Head of the Provincial Land Office or the Head of the Regency/City Land Office is carried out periodically. The Head of the Provincial Land Office or the Head of the Regency/Municipal Land Office may assign an official appointed and assisted by the PPAT Supervisory and Supervisory Council to conduct an inspection at the PPAT office.

Regarding accountability for violations of the implementation of PPAT positions, Article 12 paragraphs (1) to (3) of the Regulation of the Minister of Agrarian Affairs and Spatial Planning/Head of the National Land Agency Number 2 of 2018 concerning Guidance and Supervision of Land Deed Maker Officials, stipulates that:

(1) Supervision in the form of enforcement of the rule of law in accordance with the provisions of the legislation in the field of PPAT as referred to in Article 8 letter b is carried out on the findings of the Ministry of violations of the implementation of PPAT's position or there are complaints of alleged violations committed by PPAT.

(2) Violations committed by PPAT as referred to in paragraph (1) are:

a. violation of the implementation of PPAT positions;

b. does not carry out the obligations stipulated in the laws and regulations;

c. violate the provisions of the prohibition regulated in the legislation; and/or

d. violate the Code of Ethics.

(3) Complaints as referred to in paragraph (1) may come from:

a. communities, both individuals/legal entities; and/or

b. IPPAT.

Complaints made by the community as stated above, are made in writing to the Ministry or through the complaint website or through a report application or other means of complaint provided by the Ministry. Complaints submitted in writing by the whistleblower must meet the following conditions:

a. Must clearly state the identity of the reporter and the reported party; and

b. Attach evidence relating to the complaint.

If a PPAT is proven to have committed a violation as stated in Article 12 paragraph (2) of the Regulation of the Minister of Agrarian Affairs and Spatial Planning/Head of the National Land Agency Number 2 of 2018 concerning the Guidance and Supervision of Land Deed Making Officials, then the PPAT concerned may be subject to sanctions. The sanctions given as specified in Article 13 paragraph (1) of the Regulation of the Minister of Agrarian Affairs and Spatial Planning/Head of the National Land Agency Number 2 of 2018 concerning Guidance and Supervision of Land Deed Maker Officials, are in the form of:

a. written warning;

b. Temporary suspension;

c. Dismissal with honor; or

d. Disrespectful dismissal.

The imposition of sanctions as mentioned above will be adjusted to the quantity and quality of violations committed by the relevant PPAT. Regarding the imposition of administrative sanctions for violations of the obligations and positions of a PPAT, it is determined in Attachment II to the Regulation of the Minister of Agrarian Affairs and Spatial Planning/Head of the National Land Agency Number 2 of 2018 concerning Guidance and Supervision of Land Deed Maker Officials.

In Article 14 of the Regulation of the Minister of Agrarian Affairs and Spatial Planning/Head of the National Land Agency Number 2 of 2018 concerning the Guidance and Supervision of Land Deed Maker Officials, it is determined that:

(1) The imposition of sanctions on violations committed by PPAT in the form of a written warning as referred to in Article 13 paragraph (1) letter a, shall be carried out by the Head of the Land Office.

(2) The imposition of sanctions on violations committed by PPAT in the form of temporary suspension as referred to in Article 13 paragraph (1) letter b, shall be carried out by the Head of the BPN Regional Office.

(3) The provision of sanctions for violations committed by PPAT in the form of respectful or dishonorable dismissal as referred to in Article 13 paragraph (1) letter $\mathrm{c}$ and letter $\mathrm{d}$, is carried out by the Minister.

In the Decision of the Mataram District Court Number: 204/Pdt.G/2017/PN.Mtr, namely the Deed of 
Sale and Purchase Number: 153/2012, dated May 10, 2012, as the basis for registering the transfer of land rights over SHM SHM Number 1921/Batu Layar, covering an area of 23,334 M2, which was originally registered in the name of Soekirman and later became Fanny Djohan, is a legal act that was carried out after Soekirman as the seller in the deed died.

Based on the description above and the previous sub-chapters, it can be said that in making the deed by the relevant PPAT, the seller cannot be presented because he has died, thus the PPAT has violated the provisions of the legislation, which regulates the obligation to present the parties in the deed when making an authentic deed as evidence of the legal actions of the parties.

Thus, it can be said that the PPAT concerned has violated the provisions contained in:

a. Article 38 Government Regulation Number 24 of 1997 concerning Land Registration;

b. Article 101 Regulation of the State Minister of Agrarian Affairs/Head of the National Land Agency Number 3 of 1997 concerning Provisions for the Implementation of Government Regulation Number 24 of 1997 concerning Land Registration;

c. Article 22 Government Regulation Number 37 of 1998 concerning Position Regulations for Land Deed Making Officials as amended by Government Regulation of the Republic of Indonesia Number 24 of 2016 concerning Amendments to Government Regulations Number 37 of 1998 concerning Position Regulations for Land Deed Makers;

d. Article 52 Regulation of the Head of the National Land Agency Number 1 of 2006 concerning Provisions for the Implementation of Government Regulation Number 37 of 1998 concerning Regulations on the Position of Land Deed Maker Officials. Article 38 Government Regulation Number 24 of 1997 concerning Land Registration,

If the PPAT in question is proven to have violated the applicable provisions that the PPAT does not present both parties or one of the parties in the making of the deed of sale, then the PPAT concerned may be subject to administrative sanctions. Sanctions that can be given to the PPAT concerned are based on Article 62 of Government Regulation Number 24 of 1997 concerning Land Registration, in the form of:

A PPAT who in carrying out his duties ignores the provisions as referred to in Article 38, Article 39 and Article 40 as well as the provisions and instructions given by the Minister or an appointed Official shall be subject to administrative action in the form of a written warning to dismissal from his position as a PPAT, without reducing the possibility of being prosecuted compensation by parties who suffer losses resulting from the neglect of these provisions.

In addition to the sanctions stipulated in Government Regulation Number 24 of 1997 concerning Land Registration above, also in Attachment II to the Regulation of the Minister of Agrarian Affairs and Spatial Planning/Head of the National Land Agency Number 2 of 2018 concerning Guidance and Supervision of Land Deed Making Officials, it is determined regarding the types of violations. that can be done by PPAT as well as the sanctions that can be given.

In Appendix II of the Regulation of the Minister of Agrarian and Spatial Planning/Head of the National Land Agency Number 2 of 2018 concerning the Guidance and Supervision of Land Deed Maker Officials, it is determined the types of serious violations that can be committed by PPAT. Regarding the making of the PPAT Deed, the competent parties were not attended and at least 2 (two) witnesses were categorized as one of the types of serious violations committed by PPAT. Sanctions that can be given for the violation based on Attachment II to the Regulation of the Minister of Agrarian and Spatial Planning/Head of the National Land Agency Number 2 of 2018 concerning Guidance and Supervision of Land Deed Maker Officials are in the form of dishonorable dismissal.. ${ }^{1}$

Based on the description above, if based on the findings and evidence obtained, the PPAT concerned is proven in making the deed of sale and purchase, it is not attended by the authorized parties and at least 2 (two) witnesses, then based on the consideration of the minister, The PPAT concerned may be given a sanction in the form of dishonorable dismissal.

\section{CONCLUSION}

1. Sale and Purchase Deed Number: 153/2012 dated 10 May 2012, which was used as the basis for the transfer of land rights to SHM Number: 1921/Batu Layar in the Mataram District Court Decision Number: 204/Pdt.G/2017/PN.Mtr ., because it does not meet the requirements for the validity of an agreement as stipulated in Article 1320 of the Civil Code, especially regarding the elements of the agreement of the parties making the agreement, a cancellation can be submitted to the court. After the judge's decision stating that the sale and purchase deed is void, it will have an impact on the rights transfer agreement made by the parties. The deed of sale and purchase that has been canceled by the judge cannot be used as the basis for registering the transfer of transfer of land rights at the local Regency/Municipal Land Office. So that the land rights with

\footnotetext{
${ }^{1}$ Lampiran II Peraturan Menteri Agraria Dan Tata Ruang/Kepala Badan Pertanahan Nasional Nomor 2 Tahun 2018.
} 
SHM Number: 1921/Batu Layar will again belong to the seller which automatically becomes the rights of the heirs of Soekirman as the seller in the deed of sale and purchase.

2. The buyer who was harmed as a result of the Sale and Purchase Deed Number: 153/2012 on 10 May 2012, as the basis for the transfer of land rights to SHM Number: 1921/Batu Layar as stated in the Mataram District Court Decision Number: 204/Pdt.G /2017/PN.Mtr., can file a lawsuit to the District Court so that the PPAT concerned can be held accountable in the form of compensation for compensation costs. The amount of the compensation fee is determined by the judge based on the consideration of the available evidence. In addition to civil liability, the PPAT concerned can also be held accountable administratively, by means of a Buyer who feels aggrieved can file a complaint with the Ministry of Agrarian Affairs and Spatial Planning/Head of the National Land Agency through the official website of the relevant ministry, or a Report Application, or Complaints facility other information provided by the Ministry, by clearly stating the identity of the complainant and the reported party and attaching evidence relating to the complaint. Because in the making of the Sale and Purchase Deed as stated in the Decision, one of the parties is not present, then the PPAT can be considered to have committed one of the serious violations that can be sanctioned in the form of dishonorable dismissal.

\section{REFFERENCES}

\section{ARTICLES AND JOURNALS}

Ali, Z. (2011). Metode penelitian hukum. Sinar Grafika.

HS, H. S. (2016). Teknik Pembuatan Akta Satu: Konsep Teoritis. Kewenangan Notaris.

Leny, A. (2018). Panduan Notaris/PPAT dalam Menghadapi Gugatan Perdata. Yogyakarta: II Press Yogyakarta. Mertokusumo, S. (2009). Hukum Acara Perdata Indonesia (Edisi ke Delapan). Liberty, Yogyakarta.

Soegondo, R. (1982). Hukum Notariat di Indonesia Suatu Penjelasan. Rajawali Pers, Jakarta.

\section{REGULATIONS}

Kitab Undang-Undang Hukum Perdata;

Peraturan Menteri Agraria Dan Tata Ruang/Kepala Badan Pertanahan Nasional Nomor 2 Tahun 2018

Peraturan Pemerintah Nomor 24 Tahun 1997 tentang Pendaftaran Tanah;

Peraturan Pemerintah Nomor 37 Tahun 1998 tentang Peraturan Jabatan Pejabat Pembuat Akta Tanah;

Putusan Pengadilan Negeri Mataram Nomor 204/Pdt.G/2017/PN.Mtr.

Undang-Undang Dasar Negara Republik Indonesia Tahun 1945;

Undang-Undang Nomor 5 Tahun 1945 Tentang Peraturan Dasar Pokok-Pokok Agraria;

\section{INTERVIEW}

Wayan Parta, PPAT berkedudukan di Lombok Barat, pada tanggal 24 Mei 2021. 